\title{
Potensi Metabolit Sekunder Buah Jambu Biji (Psidium Guajava) sebagai Inhibitor Korosi Ramah Lingkungan pada Besi
}

\author{
Potency of Secondary Metabolites on Guava Fruit (Psidium Guajava) as \\ Ecofriendly Corrosion Inhibitors for Iron
}

\author{
Said Ali Akbar \\ Universitas Serambi Mekkah, Pendidikan Kimia \\ email: said.aliakbar@serambimekkah.ac.id
}

Received: 02/03/2019; Revised: 10/05/2019; Accepted: 13/05/2019

\begin{abstract}
Abstrak
Sebagai alternatif inhibitor sintetis, green inhibitor sangat berguna pada material yang tidak memungkinkan digunakan metoda proteksi secara pelapisan dan proteksi katodik. Jambu biji memiliki komponen metabolit sekunder yang dapat digunakan sebagai penghambat korosi. Buah jambu biji diekstraksi menggunakan metoda maserasi. Selanjutnya, ekstrak jambu biji dilakukan karakterisasi secara fitokimia. Kinerja inhibitor dilakukan dengan mengunakan 2 jenis air (sumur dan laut) serta variasi konsentrasi ekstrak yaitu 3\%, 10\% dan 25\%. Laju korosi pada paku menjadi semakin kecil dengan bertambahnya konsentrasi ekstrak. Pada air laut, penambahan $25 \%$ ekstrak menunjukkan kenaikan massa sebesar $0,018 \%$ dari berat paku mula-mula. Efisiensi inhibitor paling besar terjadi pada penambahan $25 \%$ ekstrak yaitu sebesar $98,39 \%$ pada media air sumur dan $99,75 \%$ pada air laut. Oleh sebab itu, jambu biji sangat berpotensi untuk digunakan sebagai aplikasi green inhibitor masa depan.
\end{abstract}

Kata kunci : inhibitor korosi, jambu biji, metabolit sekunder, ramah lingkungan

\begin{abstract}
As an alternative for synthetic inhibitor, green inhibitors are beneficial in materials that don't allow used to the coating and cathodic protection methods. Guava has a secondary metabolite component that can be used as a corrosion inhibitor. Guava fruit was extracted using the maceration method. Furthermore, guava extract was carried out phytochemical characterization. The inhibitor performance was carried out by using two types of water (wells and sea) and variations in extract concentrations with 3\%, 10\%, and 25\%. The corrosion rate on the iron become smaller with increasing extract concentration. In seawater, the addition of $25 \%$ extract shows a mass increase about $0.018 \%$ compared to the initial mass. The greatest inhibitor efficiency occurred in the addition of $25 \%$ extract, which amounted to $98.39 \%$ in well water and $99.75 \%$ in seawater. Therefore, guava has the potential used as a future green inhibitor application.
\end{abstract}

Keywords: corrosion inhibitors, environmentally friendly, guava, secondary metabolites

\section{PENDAHULUAN}

Sebagai salah satu material penunjang, penggunaan besi dalam perkembangan teknologi dan industri saat ini sangat besar peranannya. Besi banyak digunakan pada industri minyak dan gas alam, yaitu sebagai pipa penyalur proses eksplorasi dan produksi (Hu \& Shchukin, 2018). Selain itu, karena memiliki sifat mekanis yang cukup bagus, material besi dapat digunakan pada aplikasi konstruksi bangunan maupun industri kapal. Namun, 
dalam kehidupan sehari-hari banyak faktor yang menyebabkan daya guna besi ini menurun. Salah satu penyebab hal tersebut adalah terjadinya korosi pada besi. Korosi ini cukup menimbulkan kerugian, yaitu biaya perawatan, biaya penggantian material, plant shutdown, loss production, dan lain-lain. Sejauh ini, penggunaan inhibitor untuk mengurangi laju korosi telah banyak dikembangkan (Askari dkk., 2018). Keunggulannya, penambahan inhibitor ini sangat berguna pada material yang tidak memungkinkan digunakan metoda proteksi secara pelapisan dan proteksi katodik. Inhibitor bekerja dengan cara menyerap ion atau molekul yang kaya akan elektron bebas ke dalam permukaan logam melalui pembentukan senyawa komplek. Hal tersebut akan mengurangi laju difusi reaktan ke dalam permukaan logam serta menaikkan tahanan listrik permukaan logam (Rassouli $d k k$., 2018).

Sejauh ini, beberapa jenis inhibitor yang telah banyak digunakan pada aplikasi industri adalah inhibitor kimia sintesis. Inhibitor ini umumnya terbuat dari senyawa yang mengandung silikat, fosfat, borat, dikromat, molibdat, kromat, tungstat, dan arsenat (Koriem dkk., 2019; Verma $d k k$., 2018; Moradi $d k k .$, 2018; Gupta $d k k$., 2018). Namun, senyawa tersebut bersifat tidak ramah lingkungan, beracun, dan mahal. Untuk mengatasi permasalahan tersebut, pengembangan suatu inhibitor korosi alternatif yang ramah lingkungan atau lebih dikenal dengan istilah green inhibitor telah banyak dilakukan. Pada dasarnya, green inhibitor mengandung unsur $\mathrm{P}, \mathrm{S}, \mathrm{N}, \mathrm{O}$, dan unsur-unsur yang mempunyai pasangan elektron bebas (Akbar $d k k .$, 2018; Mahidashti $d k k$. , 2018). Penelitian mengenai green inhibitor dengan menggunakan gelatin pada baja dalam media larutan $\mathrm{HCl}$ telah dilaporkan (Mo dkk., 2017). Penelitian lain melalui pembuatan $\mathrm{N}$-isonicotinamido-3methoxy-4-hydroxybenzalaldimine berdasarkan vanillin dan isoniazid, dapat menahan korosi dengan efesiensi inhibitor mencapai $93 \%$ pada $120 \mathrm{mg} / \mathrm{L}$ (Haruna $d k k$., 2018). Kemudian, pemanfaatan lada hitam sebagai inhibitor korosi pada logam juga sudah dilakukan. Ekstrak lada hitam mengandung unsur nitrogen dari golongan alkaloid (Hu \& Shchukin, 2018). Penelitian lain menunjukkan bahwa ekstrak lawsonia digunakan sebagai inhibitor pada besi karbon dalam media 3,5\% $\mathrm{NaCl}$. Ekstrak tersebut memberikan efisiensi sebesar 91,01\% pada konsentrasi 800 ppm. Ekstrak lawsonia kaya akan unsur $\mathrm{O}$ dari Polifenol yaitu berupa flavonoid (Askari $d k k$., 2018).

Hasil review yang telah dilakukan tentang komposisi kimia dan aktivitas dari tumbuhan Jambu Biji (Psidium guajava) menunjukkan bahwa, pada buah Jambu Biji terkandung flavonoid golongan Quercetin dan Guaijavarin (Wang dkk., 2018; Chakraborty $d k k$., 2018). Sebagaimana diketahui flavonoid merupakan metabolit sekunder golongan polifenol yang kaya akan unsur O. Sejauh ini belum ada penelitian terkait aplikasi komponen dari buah Jambu Biji sebagai penghambat korosi. Oleh sebab itu, dalam hal ini peneliti ingin melakukan studi pada buah Jambu Biji sebagai potensi untuk dijadikan green inhibitor.

\section{METODOLOGI PENELITIAN}

\section{Alat dan bahan}

Alat yang digunakan meliputi rotary evaporator, peralatan gelas yang ada di laboratorium, ayakan 40 mesh, blender, neraca analitik, kertas saring, paku besi yang dijual di pasaran, amplas, tissu roll, corong, kertas label, pipet tetes. Selanjutnya bahan yang digunakan dalam penelitian ini 
adalah buah jambu biji merah, bahan kimia yang digunakan etanol teknis (96\%), asam klorida $(\mathrm{HCl})$, air sumur, dan air laut.

\section{Proses Ekstraksi Buah Jambu Biji}

Buah jambu biji merah dibersihkan dengan cara dicuci dengan air sumur pada suhu ruang kemudian buah jambu biji merah dipotong kecil dan ditimbang. Buah jambu biji merah dihaluskan menggunakan blender. Hasil penghalusan disaring sehingga diperoleh hasil penyaringan buah jambu biji merah berupa bubur. Bubur buah jambu biji merah ditimbang sebanyak $25 \mathrm{~g}$, selanjutnya diekstraksi dengan menggunakan metode maserasi (direndam) selama 48 jam (2 hari) dengan menggunakan pelarut etanol sebanyak $1 \mathrm{~L}$. Ekstrak etanol yang diperolah kemudian disaring dengan menggunakan saringan, sehingga filtrat dan residu dapat terpisah. Filtrat yang diperoleh diuapkan menggunakan rotary vacum evaporator pada suhu terjaga $100^{\circ} \mathrm{C}$ selama 2 jam untuk menghasilkan ekstrak buah jambu biji kental.

\section{Pengujian Kinerja Inhibitor}

Sampel paku besi dibersihkan menggunakan amplas, selanjutnya dicelupkan dalam larutan $\mathrm{HCl} 0,01 \mathrm{~N}$. Kemudian paku ini dibilas menggunakan alkohol, dicuci menggunakan aquadest, dikeringkan dan ditimbang $\left(\mathrm{W}_{\mathrm{o}}\right)$. Pengujian kinerja antikorosi pada ekstrak buah jambu dilakukan dengan menggunakan 2 jenis air yang berbeda, yaitu menggunakan air sumur dan air laut. Mula-mula wadah pengujian korosi sebanyak 4 buah diberi label paku besi I, paku besi II, paku besi III, dan paku besi IV. Kemudian masingmasing wadah diisi dengan air sumur sebanyak $10 \mathrm{~mL}$, lalu 4 buah wadah lain diisi dengan air laut (Gambar 1).

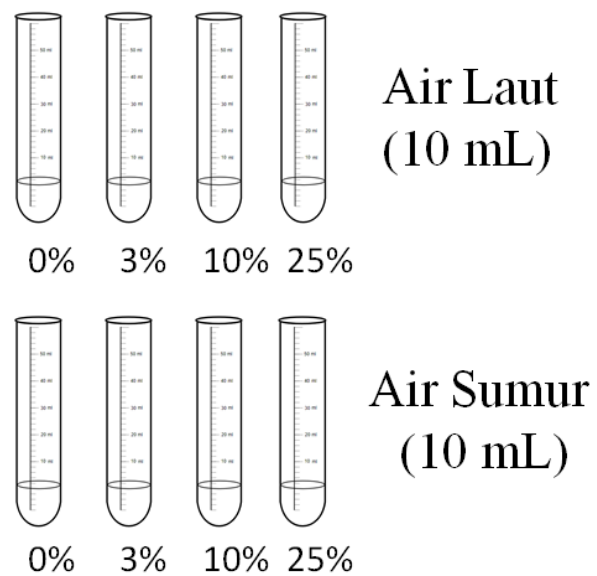

Gambar 1. Ilustrasi proses pengujian kinerja inhibitor

Selanjutnya kedalam setiap wadah dimasukkan 1 batang paku besi yang sudah dibersihkan dan sudah ditimbang beratnya. Kemudian pada wadah 2, 3, dan 4 yang masing-masing sudah diisi dengan air laut maupan sumur $10 \mathrm{~mL}$ ditambah dengan larutan inhibitor dengan masing-masing konsentrasi 3\%, 10\% dan 25\% dalam waktu perendaman selama 7 hari. Paku besi yang telah direndam kemudian diangkat, dicuci, dikeringkan, dan ditimbang $\left(\mathrm{W}_{\mathrm{f}}\right)$ untuk mengetahui bertambahnya berat pada besi. Kemudian dihitung laju korosi dan efektivitas inhibitor.

Untuk menentukan kemampuan inhibisi dari ekstrak buah dan daun jambu biji terhadap laju korosi besi secara kuantitatif, terlebih dahulu ditentukan laju korosi besi dengan menggunakan Persamaan 1 (Wysocka $d k k ., 2018$ ).

$$
r=\frac{(\mathrm{Wo}-\mathrm{Wf})}{\mathrm{Axt}}
$$

Keterangan :

$$
\begin{array}{ll}
\mathrm{r} & =\text { laju korosi }\left(\frac{\mathrm{gr}}{\mathrm{cm}^{2} \cdot \text { hari }}\right) \\
\mathrm{W}_{\mathrm{o}} & =\text { berat awal besi }(\mathrm{gr}) \\
\mathrm{Wf} & =\text { berat akhir besi }(\mathrm{gr}) \\
\mathrm{A} & =\text { luas permukaan paku besi }\left(\mathrm{cm}^{2}\right) \\
\mathrm{t} & =\text { waktu (hari) }
\end{array}
$$


Potensi Metabolit Sekunder Buah Jambu Biji (Psidium Guajava) sebagai Inhibitor Korosi Ramah Lingkungan pada Besi

\begin{tabular}{|c|c|c|c|c|}
\hline Langkah & selanjutnya adalah & Pengujian & Keberadaan & Metabolit \\
\hline
\end{tabular}
logam besi menggunakan Persamaan 2.

$$
\% E=\frac{r_{1}-r_{2}}{r_{1}} \times 100 \% \text {. }
$$

Keterangan :

$$
\begin{array}{ll}
\% \mathrm{E} & =\text { Efisiensi Inhibisi }(\%) \\
\mathrm{r}_{1} & =\text { laju korosi tanpa inhibitor } \\
\mathrm{r}_{2} & =\text { laju korosi dengan inhibitor }
\end{array}
$$

\section{HASIL DAN PEMBAHASAN \\ Proses Ekstraksi Buah Jambu Biji}

Ekstraksi buah jambu biji dilakukan dengan metode maserasi. Pertama, buah jambu biji dibersihkan dengan air aqudest, kemudian dipotong dengan ukuran kecil, lalu ditimbang. Setelah itu, buah jambu biji ditimbang lalu dihaluskan dengan menggunakan blender, kemudian diekstrak dengan menggunakan 1 liter etanol 96\% dalam wadah tupperware yang tertutup rapat selama 2 hari dengan sesekali dikocok dan dua kali diremaserasi. Setelah dimaserasi selama 2 hari, ekstrak buah jambu biji kemudian disaring agar terpisah antara residu dengan filtratnya. Setelah itu ekstrak yang diperoleh dipekatkan dengan menggunakan rotary vacum evaporator pada suhu terjaga $100^{\circ} \mathrm{C}$ selama 2 jam untuk menghasilkan ekstrak buah jambu biji kental (Gambar 2). Ekstrak buah berwarna merah jambu ditemukan saat proses maserasi hari pertama, tetapi berwarna agak coklat kehitaman setelah 2 hari pemekatan dengan destilasi.
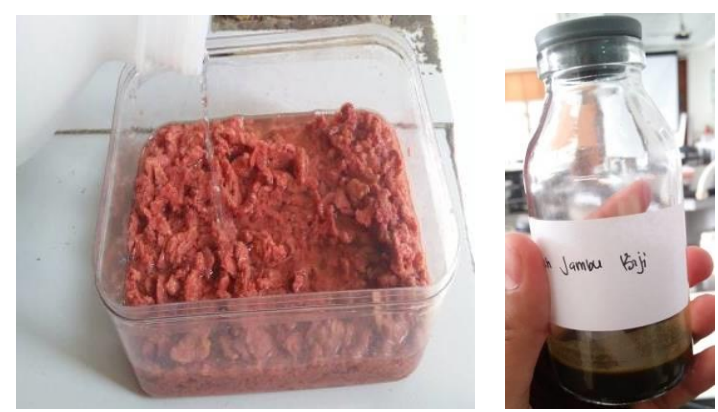

Gambar 2. Proses ekstraksi buah Jambu Biji
Pengujian fitokimia perlu dilakukan untuk menyakinkan komponen metabolit sekunder yang terkandung didalam buah jambu biji seperti alkaloid, flavanoid, saponin, terpenoid, steroid, tanin dan polifenol. Untuk hasil yang lebih jelas dapat dilihat pada Tabel 2 serta Gambar 3. Uji metabolit sekunder yang pertama yaitu uji alkaloid. Prinsip dasar dari uji ini adalah terbentuknya endapan berwarna jingga kecoklatan pada dasar tabung dari larutan dengan warna jingga (Pereaksi Dragendorff). Pada uji ini, ekstrak buah jambu biji hanya menunjukkan larutan yang berwarna kekuningan tanpa timbulnya endapan. Selanjutnya, uji flavonoid dilakukan menggunakan serbuk $\mathrm{Mg}$ dan $\mathrm{HCl}$ pekat. Pada pengujian ini, dihasilkan larutan berwarna merah kecokelatan dari ekstrak buah jambu biji yang menandakan hasil positif.

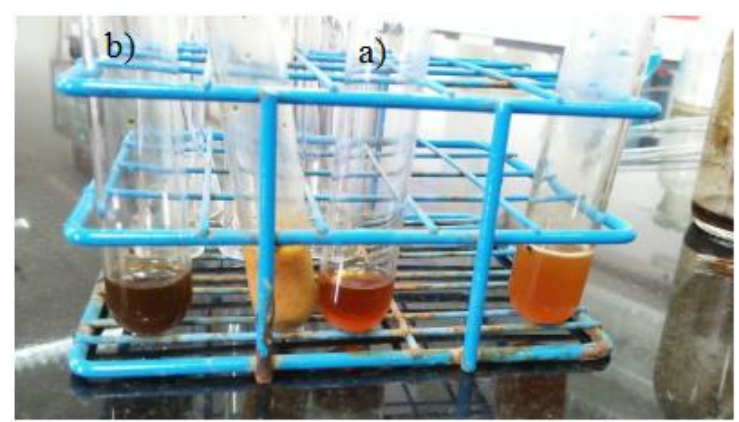

Gambar 3. Hasil uji fitokimia pada ekstrak buah jambu biji yang menunjukkan keberadaan komponen penting a) flavonoid dan b) tanin

Kemudian, pada uji saponin tidak dihasilkan larutan serta tidak terbentuknya busa yang stabil setinggi $\pm 1,5 \mathrm{~cm}$. Hal ini menandakan hasil negatif saponin pada ekstrak jambu biji. Hal serupa ditunjukkan pada uji steroid, melalui pereaksi Lieberman Burchard, ekstrak buah jambu biji tidak menunjukkan warna hijau yang 
berarti menandakan hasil negatif. Namun, ekstrak buah jambu biji menunjukkan warna ungu kehijauan yang mengindikasikan keberadaan terpenoid. Uji metabolit sekunder yang berikutnya adalah uji polifenol dan uji tanin (Wang $d k k$., 2018). Hasil uji polifenol menghasilkan larutan berwarna kekuningan yang menandakan hasil negatif. Sedangkan hasil uji tanin menghasilkan warna ungu kehijauan, hal ini mengindikasikan bahwa ekstrak buah jambu biji mengandung senyawa tanin.

Tabel 1. Hasil uji metabolit sekunder ekstrak buah jambu biji melalui fitokimia

\begin{tabular}{llc}
\hline Senyawa & Warna teramati & Keterangan \\
\hline Alkaloid & $\begin{array}{l}\text { Larutan } \\
\text { Kekuningan }\end{array}$ & - \\
\hline Flavonoid & $\begin{array}{l}\text { Merah } \\
\text { kecokelatan }\end{array}$ & + \\
\hline Saponin & $\begin{array}{l}\text { Tidak terbentuk } \\
\text { busa }\end{array}$ & - \\
\hline Steroid & Kekuningan & - \\
\hline Terpenoid & Ungu kehijauan & + \\
\hline Tanin & Ungu kehijauan & + \\
\hline Polifenol & Kekuningan & - \\
\hline
\end{tabular}

Dari hasil uji fitokimia yang telah dilakukan, secara kualitatif senyawa flavonoid terbukti ada dalam buah jambu biji yang ditandai dengan terbentuknya perubahan kekuningan dari merah jambu menjadi merah kecokelatan. Dari berbagai referensi yang didapat, komponen flavonoid dari buah jambu biji berada dalam bentuk yang sesuai dengan Gambar 4 (Chakraborty $d k k ., 2018)$.<smiles>O=c1c(OC2C(O)CC(O)C(O)OC2O)c(-c2ccc(O)c(O)c2)oc2cc(O)cc(O)c12</smiles>

(a)<smiles>O=c1c(O)c(-c2ccc(O)c(O)c2)oc2cc(O)cc(O)c12</smiles>

(b)

Gambar 4. Struktur (a) Guaijavarin dan (b) Quercetin

\section{Pengujian Kinerja Inhibitor}

Telah dilakukan pengujian sifat inhibisi ekstrak buah jambu biji terhadap paku besi, yang diterapkan pada 2 jenis media air yang berbeda, yaitu air sumur dan air laut. Pengujian ini dilakukan dalam rentang waktu perendaman selama 7 hari. Gambar 5 menunjukkan gradasi warna yang cukup mencolok dari ke 4 wadah. Terlihat wadah a) menujukkan tingkat korosi yang hampir mirip diantara kedua jenis air. Setelah 7 hari, keseluruhan paku didalam wadah dilakukan pengeringan untuk ditimbang massanya. Kemudian selisih massa setelah 7 hari dan massa awal paku merupakan massa pertambahan paku (massa karat) yang tunjukkan pada gambar 5. Pengukuran kinerja inhibitor dilakukan dalam 3 kali percobaan untuk setiap jenis air dan konsentrasi ekstraknya, sehingga persen error juga dilampirkan pada grafik guna memperlihatkan keakuratan pengukuran.

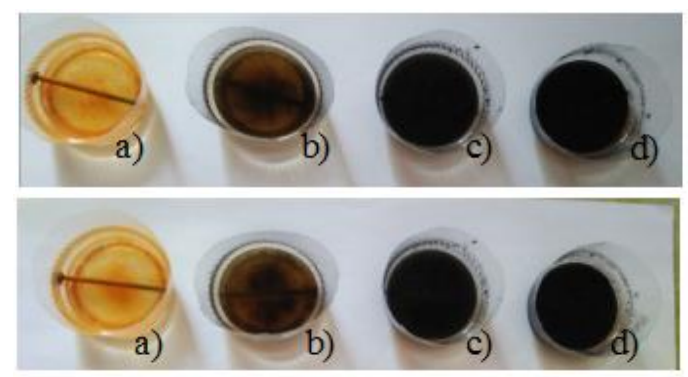

Gambar 5. Perendaman paku besi dalam air 1) sumur 2) laut, dengan penambahan ekstrak buah jambu biji sebanyak 1) 0\% 2) 3\% 3) $10 \%$ dan 4) $25 \%$, selama 7 hari 
Dari percobaan didapatkan bahwa pada wadah a) (yang tidak terdapat ekstrak buah jambu biji), baik menggunakan air sumur maupun air laut, berat paku meningkat. Nilai rata-rata berat yang bertambah sebesar $0,25 \mathrm{~g}$ pada media air sumur dan $0,41 \mathrm{~g}$ pada media air laut. Hal ini terjadi karena tidak adanya penambahan ekstrak buah jambu biji yang digunakan sebagai inhibitor alami anti korosi, sehingga karatan yang terjadi sangat banyak.

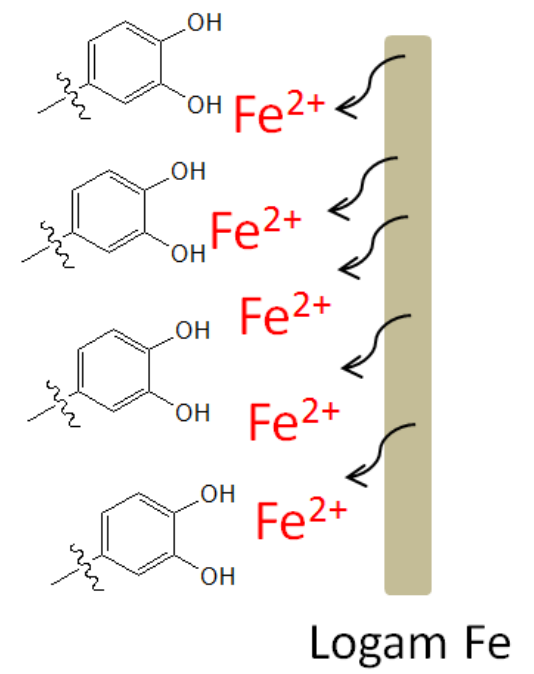

Gambar 6. Ilustrasi mekanisme inhibisi yang dilakukan komponen metabolit dalam ekstrak jambu biji.

Selanjutnya, pada wadah yang berisi ekstrak buah jambu biji yaitu wadah b), wadah c) dan wadah d) tidak terjadinya penambahan berat paku yang signifikan. Dimana pada wadah b) dengan 3\% ekstrak buah jambu biji, terjadi penambahan berat paku yang mula-mula 5,513 g menjadi $5,673 \mathrm{~g}$ pada media air sumur dan 5,216 $\mathrm{g}$ menjadi 5,506 g. Bahkan, pada wadah d) dengan 25\% ekstrak buah, menunjukkan kenaikan berat paku sebesar $0,076 \%$ dari berat paku mula-mula media air sumur dan $0,018 \%$ dari berat paku mula-mula media air laut (Gambar 7).
Hal ini membuktikan bahwa ekstrak buah jambu biji dapat dijadikan green inhibitor yang dapat menghambat terjadinya korosi pada besi baik di media air sumur maupun media air laut, dibuktikan dengan semakin berkurangnya penambahan berat paku dibandingkan dengan paku besi yang tidak diberi inhibitor. Komponen metabolit sekunder didalam ekstrak jambu biji kaya akan atom oksigen golongan polifenol. Pada saat logam Fe terjadi korosi, maka ion $\mathrm{Fe}^{2+}$ yang dihasilkan teradsorpsi pada sisi aktif atom oksigen dari metabolit sekunder. Proses ini lama kelamaan akan membentuk suatu lapisan inert yang tidak memungkinkan oksigen untuk mengoksidasi kembali permukaan Fe (Gambar 6).

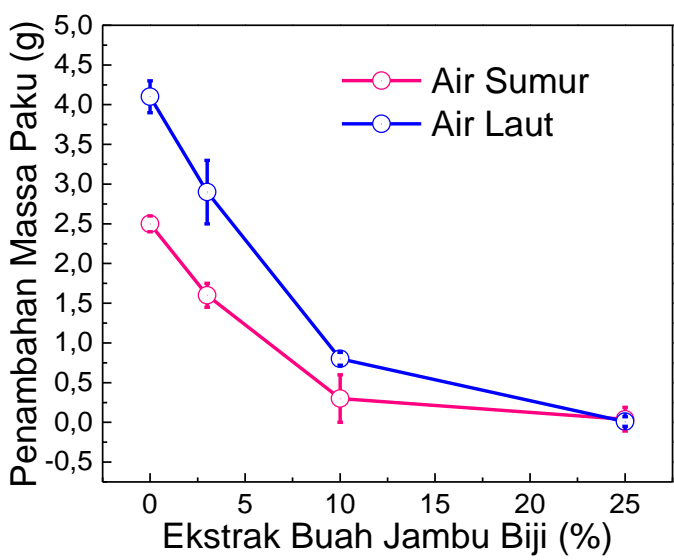

Gambar 7. Grafik penambahan massa logam paku selama perendaman 7 hari

Oleh sebab itu, peningkatan konsentrasi inhibitor menyebabkan molekul inhibitor lebih banyak untuk teradsorpsi pada permukaan logam, dengan menyediakan cakupan permukaan lebih luas melalui senyawa metabolit yang bertindak sebagai inhibitor adsorpsi. Semakin besar konsentrasi ekstrak buah jambu yang digunakan sebagai inhibitor korosi, penambahan berat paku semakin mengecil bahkan tidak bertambah sama sekali, berat paku sebelum perendaman dan sesudah 
Potensi Metabolit Sekunder Buah Jambu Biji (Psidium Guajava) sebagai Inhibitor Korosi Ramah Lingkungan pada Besi

perendaman hampir tidak menunjukkan adanya perbedaan.

\section{Penentuan Laju Korosi dan Efektifitas Inhibitor}

Untuk menentukan kemampuan inhibisi dari ekstrak buah jambu biji terhadap laju korosi besi secara kualitatif, terlebih dahulu ditentukan laju korosi besi dengan membagi penambahan massa besi terhadap luar permukaan paku dan waktu. Pengaruh variasi konsentrasi ekstrak buah jambu biji terhadap perendaman paku besi dalam media air sumur maupun media air laut dapat dilihat pada Tabel 2. Berdasarkan hasil dari penelitian nilai laju korosi, untuk larutan yang tidak diberi ekstrak, laju korosi yang paling cepat terjadi pada konsentrasi $0 \%$ yaitu sebesar $0,000379 \mathrm{~g} / \mathrm{cm}^{2}$.hari pada media air sumur dan sebesar 0,000622 $\mathrm{g} / \mathrm{cm}^{2}$.hari pada media air laut. Seiring bertambahnya ekstrak buah jambu biji, maka laju korosi manjadi lebih lambat. Terlihat laju korosi paling lambat terjadi pada konsentrasi $25 \%$ yaitu sebesar $0,00000607 \mathrm{~g} / \mathrm{cm}^{2}$.hari pada media air sumur dan $0,00000152 \mathrm{~g} / \mathrm{cm}^{2}$.hari pada media air laut.

Setelah didapatkan laju korosi paku besi, langkah selanjutnya adalah menentukan efektifitas inhibisi korosi logam besi. Potensi ekstrak buah jambu biji sebagai inhibitor korosi pada paku besi dalam air sumur dan air laut dapat ditentukan berdasarkan nilai efisiensi inhibisi yang dapat dihitung sehingga diperoleh nilai efisiensi inhibisi seperti ditunjukkan pada Gambar 8. Efisiensi inhibitor yang paling besar terjadi pada $25 \%$ konsentrasi ekstrak yaitu sebesar 98,39\% pada media air sumur dan sebesar 99,75\% pada media air laut. Efisiensi inhibitor yang terkecil terjadi pada saat konsentrasi $3 \%$ yaitu sebesar $35,97 \%$ pada media air sumur dan sebesar $29,29 \%$ pada media air laut.

Peningkatan konsentrasi inhibitor menyebabkan molekul inhibitor lebih banyak untuk teradsorpsi pada permukaan logam, menyediakan cakupan permukaan lebih dengan senyawa bertindak sebagai inhibitor adsorpsi (Wysocka dkk., 2018; Saviour $d k k ., 2018)$. Peningkatan konsentrasi inhibitor kimia cenderung berbanding lurus dengan meningkatnya efisiensi inhibisi (Moradi dkk., 2018). Secara struktur molekul, nilai efisiensi inhibisi yang baik dapat disebabkan oleh kehadiran struktur heterosiklik/aromatik dan dari hasil yang didapatkan mengindikasikan senyawa aktif flavonoid dalam ekstrak buah jambu biji berperan aktif meningkatkan efisiensi inhibitor.

Tabel 2. Laju korosi pada paku besi dengan berbagai konsentrasi ekstrak jambu biji dan jenis air

\begin{tabular}{|c|c|c|c|c|c|c|}
\hline \multirow{3}{*}{$\begin{array}{c}\text { Ekstrak } \\
(\%)\end{array}$} & \multicolumn{3}{|c|}{ Air Sumur } & \multicolumn{3}{|c|}{ Air Laut } \\
\hline & \multicolumn{2}{|c|}{ Massa Paku } & \multirow{2}{*}{$\begin{array}{l}\text { Laju korosi } \\
\text { (g/cm².hari) }\end{array}$} & \multicolumn{2}{|c|}{ Massa Paku } & \multirow{2}{*}{$\begin{array}{l}\text { Laju korosi } \\
\left(\mathrm{g} / \mathrm{cm}^{2} . h a r i\right)\end{array}$} \\
\hline & Awal (g) & Akhir (g) & & Awal (g) & Akhir (g) & \\
\hline 0 & 5,819 & 6,069 & 0,000379 & 5,709 & 6,119 & 0,000622 \\
\hline 3 & 5,513 & 5,673 & 0,000243 & 5,216 & 5,506 & 0,00044 \\
\hline 10 & 5,622 & 5,652 & 0,0000455 & 5,412 & 5,492 & 0,000121 \\
\hline 25 & 5,240 & 5,244 & 0,00000607 & 5,542 & 5,543 & 0,00000152 \\
\hline
\end{tabular}


Potensi Metabolit Sekunder Buah Jambu Biji (Psidium Guajava) sebagai Inhibitor Korosi Ramah Lingkungan pada Besi

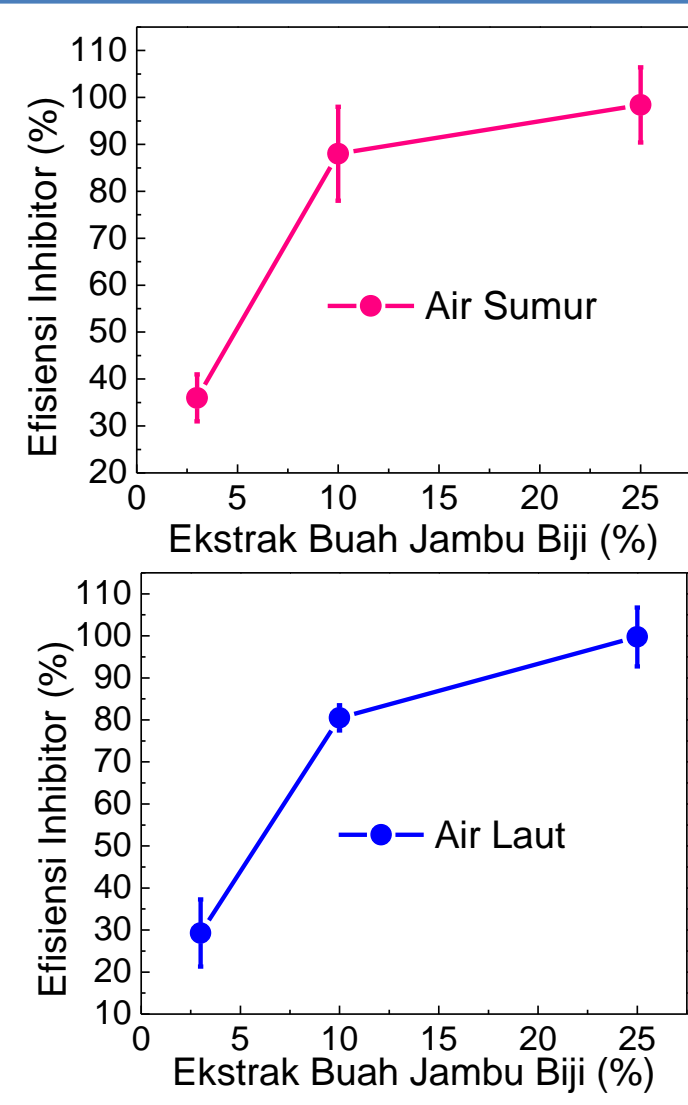

Gambar 8. Grafik efisiensi inhibisi dari ekstrak buah jambu biji

\section{KESIMPULAN}

Komponen metabolit sekunder aktif yang terkandung didalam buah jambu biji adalah flavonoid, terpenoid, dan tanin. Hal ini ditunjukkan melalui serangkaian tes screening fotokimia pada ekstrak buah. Bertambahnya konsentrasi ekstrak buah jambu biji dalam sampel air sumur dan laut, memperkecil nilai laju korosi sebagai fungsi dari penambahan berat paku. Penggunaan 3\% ekstrak buah jambu biji mengakibatkan penambahan berat paku yang mula-mula 5,513 g menjadi $5,673 \mathrm{~g}$ pada media air sumur dan 5,216 g menjadi 5,506 g. Bahkan, dengan 25\% ekstrak buah, kenaikan berat paku menjadi 0,076\% dari berat paku mula-mula media air sumur dan $0,018 \%$ dari berat paku mula-mula media air laut. Selanjutnya, efisiensi inhibitor yang paling besar terjadi pada $25 \%$ konsentrasi ekstrak yaitu sebesar
98,39\% pada media air sumur dan sebesar 99,75\% pada media air laut. Oleh sebab itu, jambu biji sangat berpotensi untuk digunakan sebagai aplikasi green inhibitor masa depan.

\section{UCAPAN TERIMA KASIH}

Penulis mengucapkan terima kasih kepada LPPM Universitas Serambi Mekkah atas segala finansialnya memberikan dukungan terhadap penelitian ini.

\section{DAFTAR RUJUKAN}

Akbar, S. A., Armelianda, D., \& Muttakin, M. (2018). Electrolyte Performance of Noni Fruit Extracts (Morinda Citrifolia L.) for $\mathrm{C}-\mathrm{Zn}$ Batteries, CHEESA: Chemical Engineering Research Articles, 1(2): 74-81.

Askari, M., Aliofkhazraei, M., Ghaffari, S., \& Hajizadeh, A. (2018). Film former corrosion inhibitors for oil and gas pipelines - A technical review, J Nat Gas Sci Eng, 58, 92-114.

Chakraborty, S., Afaq, N., Singh, N., \& Majumdar, S. (2018). Antimicrobial activity of Cannabis sativa, Thuja orientalis and Psidium guajava leaf extracts against methicillin-resistant Staphylococcus aureus, J. Integr. Med, 16(5), 350-357.

Gupta, R., Malik, P., Das, N., \& Singh, M. (2019). Antioxidant and physicochemical study of Psidium guajava prepared zinc oxide nanoparticles, J Mol Liq, 275, 749767.

Haruna, K., Obot, I. B., Ankah, N. K., Sorour, A. A., \& Saleh, T. A. (2018). Gelatin: A green corrosion inhibitor for carbon steel in oil well acidizing environment, J Mol Liq, 264, 515525 . 
Hu, W., Li, C., \& Shchukin, D. G. (2018). Ceramic honeycomb-like alumina film as corrosion inhibitor carrier and mechanism analysis, Colloids Surf. A, 555, 237-245.

Koriem, K. M. M., Arbid, M. S., \& Saleh, H. N. (2019). Antidiarrheal and protein conservative activities of Psidium guajava in diarrheal rats, $J$ Integr Med, 17(1), 57-65.

Mahidashti, Z., Shahrabi, T., \& Ramezanzadeh, B. (2018). The role of post-treatment of an ecofriendly cerium nanostructure Conversion coating by green corrosion inhibitor on the adhesion and corrosion protection properties of the epoxy coating, Prog Org Coat, 114, 19-32.

Mo, S., Li, L. J., Luo, H, Q., \& Li, N. B. (2017). An example of green copper corrosion inhibitors derived from flavor and medicine: Vanillin and isoniazid, J Mol Liq, 242, 822-830.

Moradi, M., Song, Z., \& Xiao, T. (2018). Exopolysaccharide produced by Vibrio neocaledonicus sp. as a green corrosion inhibitor: Production and structural characterization, Mater Sci Technol, 34, 2447-2457.

Rassouli, L., Naderi, R., \& Mahdavain, M. (2018). Study of the impact of sequence of corrosion inhibitor doping in zeolite on the self-healing properties of silane sol-gel film, Ind. Eng. Chem. Res, 66, 221-230.

Saviour, A., Umoren., Abdullah, A., Ahmary, A., Gasem, Z. M., \& Solomon, M. M. (2018). Evaluation of chitosan and carboxymethyl cellulose as ecofriendly corrosion inhibitors for steel, Int. J. Biol. Macromol, 117, 1017-1028.
Verma, C., Ebenso, E. E., Bahadur I., \& Quraishi, M. A. (2018). An overview on plant extracts as environmental sustainable and green corrosion inhibitors for metals and alloys in aggressive corrosive media, $\mathrm{J} \mathrm{Mol}$ Liq, 266, 577-590.

Wang, L., Lu, F., Liu, Y., Wu, Y., \& Wu, Z. (2018). Photocatalytic degradation of organic dyes and antimicrobial activity of silver nanoparticles fast synthesized by flavonoids fraction of Psidium guajava L. leaves, $J \mathrm{Mol}$ Liq, 263, 187-192.

Wysocka, J., Cieslik, M., Krakowiak, S., \& Ryl, J. (2018). Carboxylic acids as efficient corrosion inhibitors of aluminium alloys in alkaline media, Electrochim. Acta, 289, 175-192. 